\title{
Bacterial growth efficiency in lakewater cultures
}

\author{
Morten Søndergaard*, Jon Theil-Nielsen
}

Freshwater Biological Laboratory, University of Copenhagen, Helsingørsgade 51, DK-3400 Hillerød, Denmark

\begin{abstract}
Batch cultures of natural bacterial assemblages from 3 lakes were used to measure bacterial growth efficiency (BGE) from increments in biomass and oxygen uptake. As could be expected from previous results and a logistic growth model, the growth efficiency varied among experiments and changed over time in relation to growth phases. During each experiment a maximum efficiency (range from 38 to $76 \%$ ), which often coincided with maximum growth rate, could be identified. However, a significant relationship between efficiency and growth rate was not present and 2 cases of high efficiency during the apparent stationary phase were observed. Calculations of BGE by averaging procedures like linear regression of biomass increase and oxygen uptake versus time or end-point data at an apparent stationary phase most often resulted in low efficiency estimates. The maximum BGE values were on average 1.6 to 1.8 times higher than values calculated from regressions. We suggest to identify the maximum value in future measurements of BGE to avoid an underestimation of BGE. These findings are discussed in relation to in situ growth efficiency.
\end{abstract}

KEY WORDS: Lake water cultures - Bacterial growth efficiency

\section{INTRODUCTION}

Knowledge of bacterial growth efficiency is a prerequisite for the use of bacterial production measurements to evaluate the role of bacteria in plankton metabolism. Although the conversion of bacterial production to gross carbon flux with a constant efficiency factor has often been attempted (e.g. Azam et al. 1983. Riemann \& Søndergaard 1986, Baines \& Pace 1991), published efficiencies with a range covering 2 decades have made this exercise somewhat elusive. Growth efficiency seems to vary in time and space (Kroer 1993, Middelboe \& Søndergaard 1993, Russell \& Cook 1995), within single species (Ho \& Payne 1979), and over diel cycles (Coffin et al. 1993). At present there is no method available to measure true in situ growth efficiency.

Among the variables controlling growth efficiency, the most prominent are substrate $\mathrm{C} / \mathrm{N}$ ratio, inorganic nutrient availability, and substrate complexity (Linley \& Newell 1984, Goldman et al. 1987, Benner et al. 1988, Middelboe \& Søndergaard 1993). System depen-

\footnotetext{
•E-mail: flabms@inet.uni-c.dk
}

dent variations, with lower efficiency in oligotrophic as opposed to more productive marine areas, have also been reported (Griffith et al. 1990, Biddanda et al. 1994, Pomeroy et al. 1995, Carlson \& Ducklow 1996). Furthermore, bacterial growth efficiency is positively related to growth rate (Pirt 1982, Middelboe et al. 1992). The use of a variety of organic substrates like macrophyte and phytoplankton debris and naturally occurring dissolved organic carbon (DOC) has shown growth efficiency under aerobic conditions to range from 0.4 to a maximum of $80 \%$ (e.g. Linley \& Newell 1984, Bjørnsen 1986, Schwærter et al. 1988, Goldman et al. 1987, Tranvik 1988, Coffin et al. 1993, Kroer 1993, Middelboe \& Søndergaard 1993, Carlson \& Ducklow 1996, Cherrier et al. 1996).

Recent estimates of bacterioplankton growth efficiency at ambient DOC concentrations in both lakes and marine systems most often fall within the range 30 to $60 \%$ (see Cole \& Pace 1995), but with exceptions like recently published low values between 3 and $20 \%$ in oligotrophic marine areas (Carlson \& Ducklow 1996, Cherrier et al. 1996).

Most experiments concerning growth efficiency have been carried out with the purpose of extrapolating to in situ values and 2 experimental approaches 
are most often used. (1) Concurrent measurements of whole community respiration and bacterial net production (Pomeroy et al. 1995). Ideally this approach constrains the lowest possible efficiency. An approximation to in situ growth efficiency assumes an ability to estimate the respiration attributed by bacteria. (2) The second approach is to follow bacterial growth and metabolism in batch cultures. Separation from other biotic components is done either by a size selective filtration ( 1 to $2 \mu \mathrm{m}$ pore-size), ideally allowing only bacteria to pass the filter (Schwærter et al. 1988, Kirchman et al. 1991, Coffin et al. 1993, Biddanda et al. 1994), or by dilution of small natural bacteria (a 0.6 to $0.8 \mu \mathrm{m}$ pore-size filtrate aliquot) in filter-sterilized water (Bjørnsen 1986, Tranvik 1988, Middelboe et al. 1992, Kroer 1993). Calculation of growth efficiency is based on measurements of biomass increase [cell abundance and biovolume or particulate organic carbon (POC)], respiration loxygen uptake or carbon dioxide production), and total substrate utilization (decrease in DOC).

Growth experiments have the advantage and prerequisite for efficiency calculations that only bacteria are present or totally dominant in the incubation bottles. The major disadvantage is the uncoupling of bacterial metabolism from substrate production by phytoplankton exudation, zooplankton activity, and photolysis and from nutrient regeneration. While the latter problem can be overcome by additions of inorganic nutrients, the uncoupling from substrate production could result in low efficiency values caused by a bias towards bacterial utilization of organic matter with long turnover times. A rapid exhaustion of readily available monomers utilized with high efficiencies (Connolly et al. 1992) is expected to take place in a culture. Thus, metabolic activity at time zero and shortly thereafter during the exponential growth phase is understood to represent 'true' in situ rates. However, this is rarely specified. Although major changes in oxygen and bacterial production have been observed after short incubation times with 1 or $2 \mu \mathrm{m}$ filtrates ( 6 to $12 \mathrm{~h}$; Connolly et al. 1992, Coffin et al. 1993, Biddanda et al. 1994), such values are often averaged and variations in growth efficiency are partly neglected (but see Cárlson \& Ducklow 1996).

It is the purpose of the present study to measure bacterial growth efficiency in experiments with natural lake water DOC and to assess the consequences of incubation time and type of calculation. The experiments were carried out with water from 3 Danish lakes and basically represent the 'classical' growth experiment in filtered water. Bacterial biomass increment and respiration were measured directly as POC and oxygen consumption.

\section{MATERIALS AND METHODS}

Sampling sites. Samples were collected during 1994 and 1995 in 3 Danish lakes: 2 hypereutrophic lakes (Frederiksborg Slotssø and Stigsholm) and 1 mesoeutrophic lake (Esrum). Frederiksborg Slotssø and Esrum were sampled 5 or 6 times and Stigsholm was visited once. All samples were collected at midday from $0.5 \mathrm{~m}$ depth and transported cold and in the dark to the laboratory. Experiments were initiated within 2 h after sampling.

Analyses. Changes in oxygen concentration over time was measured by the micro-Winkler method using automatic and potentiometric end-point detection ( $\mathrm{Ra}$ diometers' pH-meter, titrator and burette). Samples were preserved in either 25 or $50 \mathrm{ml} \mathrm{BOD} \mathrm{(biological}$ oxygen demand) bottles (Schwarter et al. 1988). The protocol gave a precision of $0.5 \%$ (coefficient of variation, CV) among bottles and a 95\% CI (confidence interval) smaller than $0.5 \mu \mathrm{M}$. In experiments with 'plastic bags' as incubation chambers (see below), oxygen was analyzed in triplicate, while 2 BOD bottles were harvested in experiments using bottles. The advantage of bags for incubations is that all samples in a time-series can be taken from 1 container without exposure to air (Coffin et al. 1993). After testing 3 brands of commercial intravenous bags for oxygen diffusion, we found the diffusion constants too high for our purpose (>0.05 $\mathrm{h}^{-1}$ at $40 \%$ oxygen deficit), and constructed our own $2 \mathrm{l}$ bags from polyester/polythene (Ril-O-Ten-Xi Hansen et al. 1993). This material proved to have an undetectable diffusion of oxygen (Fig. 1). All experiments were initiated at oxygen saturation and the maximum decrease during an experiment was about $40 \%$ of the initial oxygen concentration.

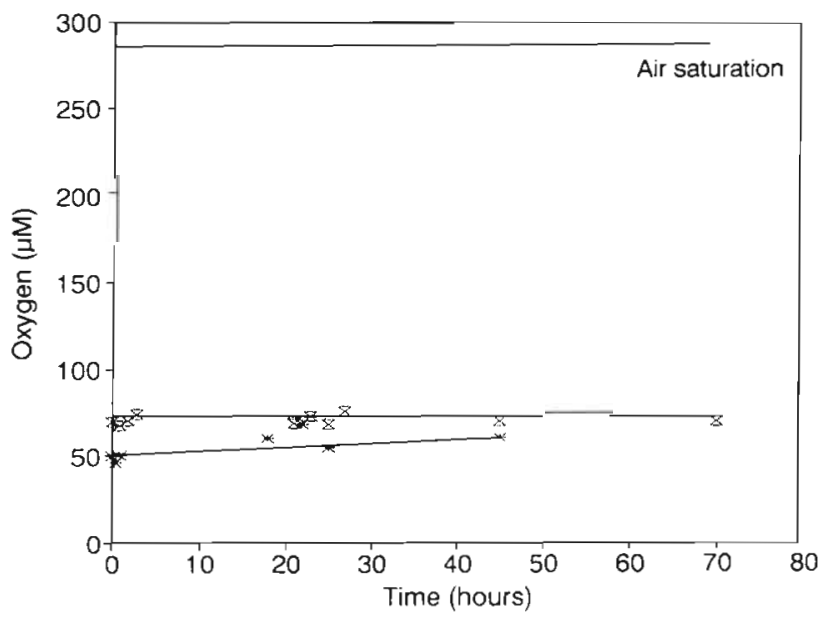

Fig. 1. Two tests of oxygen diffusion through Ril-O-Ten-X bags filled with $\mathrm{N}_{2}$-bubbled Milli- $Q$ water. The slopes of oxygen concentration versus time are not different from zero $(p<0.001)$ 
Enumeration of bacteria and survey of flagellate contamination were done by epifluorescence microscopy after DAPI staining (Porter \& Feig 1980) of glutaraldehyde preserved samples ( $2 \%$ final conc.). Slides for bacteria and flagellates were prepared from black $0.2 \mu \mathrm{m}$ polycarbonate filters within $24 \mathrm{~h}$ after sampling. Bacterial growth rates were calculated assuming exponential growth. Presence of flagellates $\left(>10 \mathrm{ml}^{-1}\right.$ ) resulted in abandonment of the experiment

POC was used as a direct measurement of bacterial biomass in carbon units. POC was measured on precombusted GF/F filters after high-temperature combustion in a home-made POC-analyzer (Søndergaard \& Middelboe 1993). The precision was better than $8 \%$ $(\mathrm{CV})$ and a difference of about $1.5 \mu \mathrm{M}$ could be detected. As the non-biotic POC background can be high in these types of incubations (Søndergaard \& Middelboe 1993), it is important to subtract time zero samples. Loss of small bacteria through GF/F filters has been reported (Søndergaard \& Middelboe 1993). However, as the number and biomass of small bacteria $(<0.4 \mu \mathrm{m})$ in the cultures were low and bacteria $>0.4 \mu \mathrm{m}$ are retained quantitatively by GF/F filters (Søndergaard \& Middelboe 1993), the maximum underestimation of bacterial biomass (POC) is approximately 5 to $8 \%$. The consequence is a slight underestimation of the growth efficiencies.

Experiments. Growth of bacteria and oxygen utilization were measured over time in either $1.0 \mu \mathrm{m}$ poresize filtrates (polycarbonate filters) or, in 1 case, a GF/F filtrate (Stigsholm). The latter experiment resembled growth of a diluted assemblage due to a low initial bacterial abundance. Before we were able to construct airtight bags for incubation, the experiments were carried out in precombusted BOD bottles. Thus, POC and bacteria on the one hand and oxygen on the other had to be measured in separate bottles. This protocol could result in anomalies between bottles, e.g. flagellate development in some bottles. The good precision between replicate oxygen bottles implies that this potential problem is a minor one.

To avoid nutrient limitation during incubation, inorganic $\mathrm{N}\left(\mathrm{NH}_{4}{ }^{+}\right)$and $\mathrm{P}$ were added to allow a bacterial

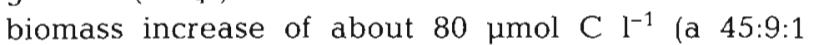
$\mathrm{C}: \mathrm{N}: \mathrm{P}$ ratio by atoms; Goldman et al. 1987). Addition of inorganic nutrients might increase the growth efficiency compared with that in situ. However, as addition of nutrients does not enhance the utilization of DOC in these eutrophic lakes (Søndergaard unpubl.) the rationale for nutrient addition is precautionary and done to secure a measurement of growth efficiency when energy (DOC) becomes limiting in the cultures. The incubations were performed with slow shaking in the dark at $16^{\circ} \mathrm{C}$ and the duration ranged from 46 to $340 \mathrm{~h}$.
Bacterial growth efficiency (BGE) was calculated as net POC increase divided by net POC increase + oxygen uptake. The calculation in time-steps between each sampling was used to identify the maximum growth efficiency $\left(\mathrm{BGE}_{\max }\right)$. Carbon equivalents were calculated assuming the respiratory quotient (RQ) to be 1. Linear regressions of POC increase and oxygen decrease versus time were used to calculate the growth efficiency $\left(\mathrm{BGE}_{\mathrm{tume}}\right)$ during the period when POC increased. Bjornsen \& Kuparinen (1991) suggested analyzing growth efficiency by a plot of bacterial biomass versus DOC utilization (biomass + respiration as a surrogate for DOC uptake), where time is removed as the independent variable and the effect of small changes over time is minimized. The progession of the curve is a visualization of the growth efficiency calculated in time steps. A linear progression would infer constant efficiency. The inherent autocorrelation, however, must not be neglected and excludes statistical analysis. A plot of POC versus $\mathrm{O}_{2}$ uptake can fulfil the visual purpose.

\section{RESULTS}

Exemplary time courses of bacterial growth and oxygen utilization in 1 long-term bottle experiment and 1 short-term bag experiment are presented in Figs. 2 \& 3, respectively. The results from Stigsholm showed an apparent linear oxygen uptake, while the abundance of bacterial cells showed a logistic growth curve and reached the stationary phase after about $140 \mathrm{~h}$ (Fig. 2A). The continued increase of POC in the stationary phase (judged by cell numbers) was due to an increase in bacterial cell size. The growth efficiency peaked after $48 \mathrm{~h}$ at $49 \%$ $\left(\mathrm{BGE}_{\max }\right)$, decreased to a minimum of $16 \%$ after $140 \mathrm{~h}$, and then again increased to about $38 \%$ (Fig. 2B). Despite the long incubation time the bioavailable DOC pool was not exhausted. Bacterial growth efficiency calculated from the linear regression equations of $\mathrm{POC}$ and $\mathrm{O}_{2}$ versus time ( $\mathrm{BGE}_{\text {time }}$ ) had an average of $25 \%$ for the entire experiment and $29 \%$ for the initial $48 \mathrm{~h}$ (Table 1 ). The plot of POC versus $\mathrm{O}_{2}$ revealed the development of $\mathrm{BGE}$ from the addition of POC increase and $\mathrm{O}_{2}$ uptake between each time interval (Fig. 4A).

The incubation bags were used for experiments with water from Frederiksborg Slotssø and Esrum. One experiment from Esrum is shown in Fig. 3. The growth efficiency calculated in time-steps initially increased from $23 \%$ to a peak of $38 \%$ after about $12 \mathrm{~h}$ and then decreased and approached zero (Fig. 3B). Linear regressions of $\mathrm{POC}$ and $\mathrm{O}_{2}$ versus time for the initial 28 h resulted in a $B G E_{\text {time }}$ of $22 \%$ (Table 1 ). As opposed 


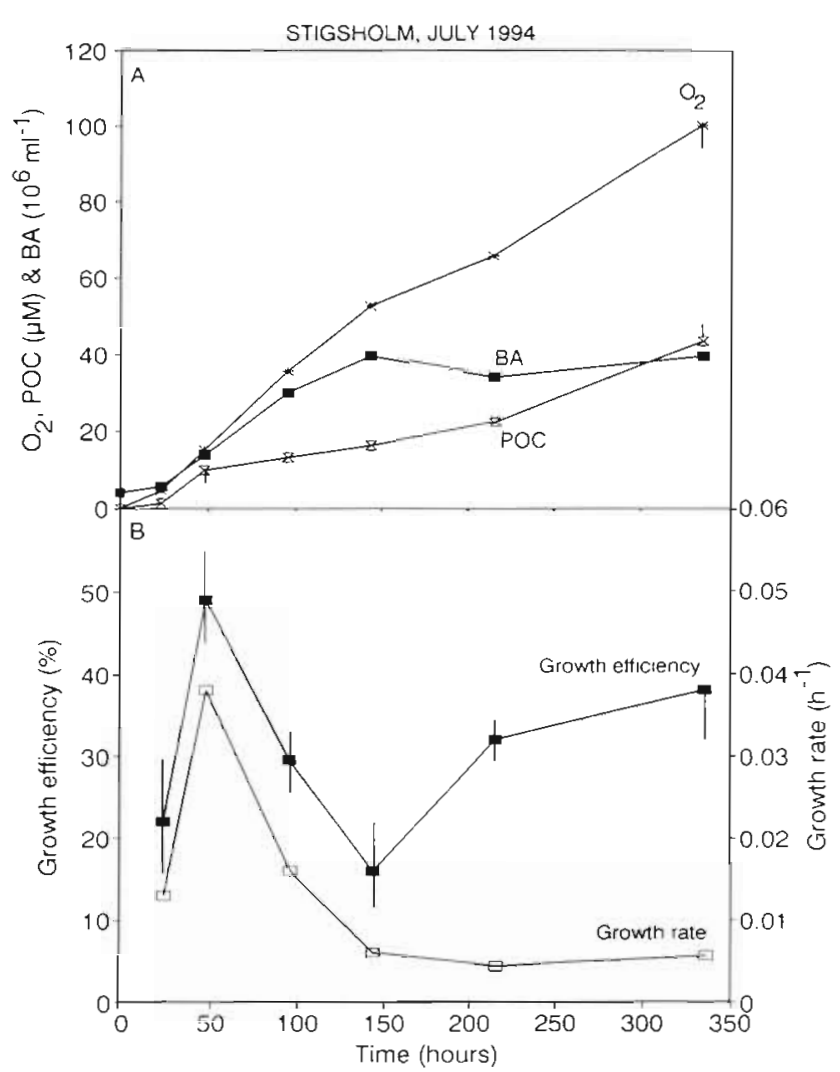

Fig. 2. (A) Oxygen consumption, bacterial abundance (BA), and POC in a growth experiment from Stigsholm. Means \pm SD $\mathrm{n}=3$, most error bars within markers. Linear regression lines POC, $0.26+0.122 \times( \pm 0.009), r^{2}=0.98 ; O_{2}, 1.97+0.30 \times( \pm 0.01)$ $r^{2}=0.98$. (B) Bacterial growth efficiencies and growth rates calculated between each sampling time. Efficiency versus growth rate has a correlation coefficient of 0.68

to the time sequence for Stigsholm, BGE did not increase later during the incubation and efficiencies and growth rates correlated significantly $\left(\mathrm{r}^{2}=0.85, \mathrm{n}=\right.$ 5 ; see Fig. 3B) in comparison with the non-significant data $\left(\mathrm{r}^{2}=0.46, \mathrm{n}=6\right.$ ) from Stigsholm (Fig. 2B). The POC versus $\mathrm{O}_{2}$ plot from Esrum visualized the development with an initial high slope and ended with a negative slope, which was due to a decrease in POC for the last measurement (Fig. 4A).

The development of BGE is further exemplified by 5 POC versus $\mathrm{O}_{2}$ plots in Fig. $4 \mathrm{~B}$ and the time sequence of the relative BGEs from Frederiksborg Slotssø (Fig. 5). In 8 of 9 experiments (Fig. 4 \& 5) the highest growth efficiency occurred shortly after the lag phase, which lasted about 10 to $24 \mathrm{~h}$. In 6 experiments BGE declined after the peak and eventually approached zero; however, a second peak occurred in 1 experiment from Frederiksborg Slotssø (Fig. 5) and the Stigsholm experiment (Fig. 2B). In 1 experiment from Esrum the efficiency remained constant over the experimental period (Fig. 4B).

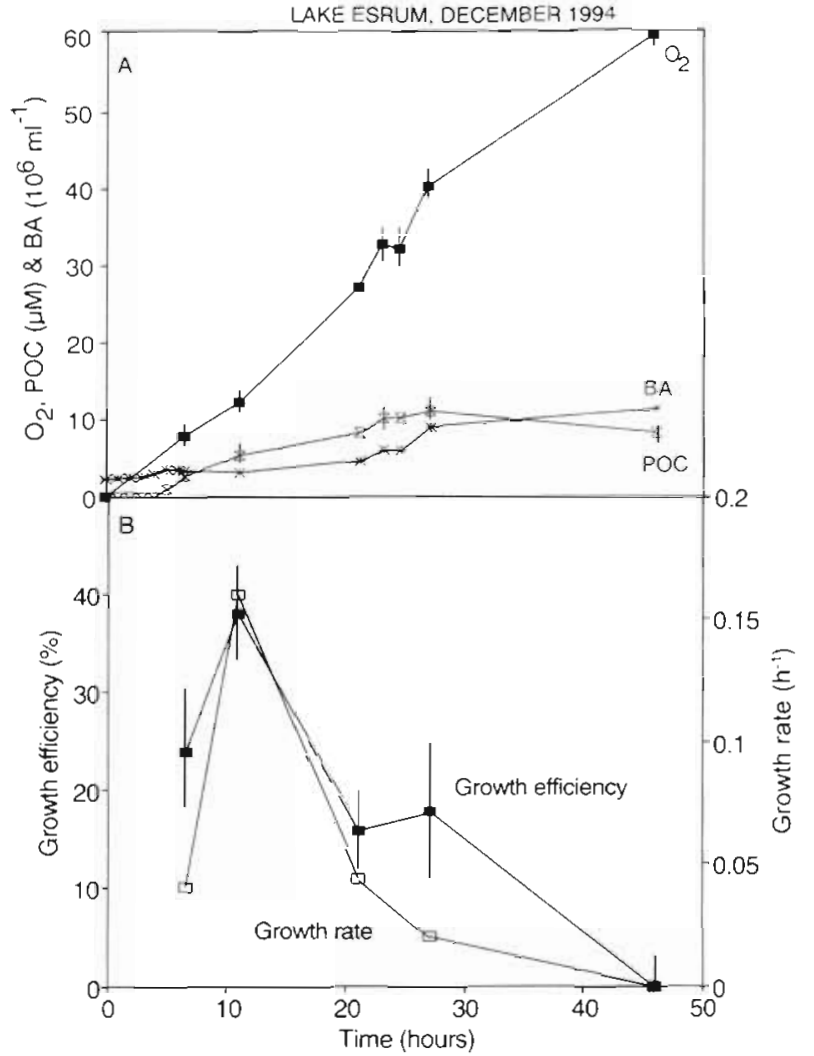

Fig. 3. (A) Oxygen consumption, bacterial abundance (BA). and $\mathrm{POC}$ in a growth experiment from Esrum. Means \pm SD, $\mathrm{n}=3$. Linear regression lines: POC, $0.14+0.397 x( \pm 0.018)$, $r^{2}=0.99 ; O_{2},-0.32+1.44 x( \pm 0.06), r^{2}=0.98$. (B) Bacterial growth efficiency and growth rates calculated between each sampling time. Efficiency versus growth rate has a correlation coefficient of 0.92

Previous investigations have shown growth efficiency to be positively related to growth rate (Middelboe et al. 1992), which is the theoretical expectation (Pirt 1982). The results from Stigsholm (Fig. 2B) and especially Esrum (Fig. 3B) also point to a positive relationship. However, compiling all data did not result in any significant correlation, but did show an overall positive trend (Fig. 6). Although most individual experiments had maximum growth efficiency concomitant with maximum growth rate, a significant correlation was not present for the relative values of efficiency and growth rate (unified by the maximum values) calculated for each experiment.

In Esrum the maximum growth efficiencies ranged from 38 to $76 \%$ and a comparison of $\mathrm{BGE}_{\max }$ and $B G E_{\text {time }}$ showed 6 out of 7 experiments where the maximum values were from 1.4 - to 3.3- and on average 1.8fold higher than $\mathrm{BGE}_{\text {ume }}$ (Table 1). In Frederiksborg Slotsse $B G E_{\max }$ ranged from 40 to $67 \%$ and was on average 1.6-fold higher than $\mathrm{BGE}_{\text {time }}$ while $B G E_{\max }$ in Stigsholm was 1.8-fold higher than BGE time $_{\text {(Table 1) }}$ 
Table 1. Comparison of growth efficiency (mean $\pm \mathrm{SD}$ ) calculated by linear regressions versus time $\left(\mathrm{BGE}_{4 \mathrm{mc}}\right)$ and maximum values $\left(B G E_{m a x}\right)$ calculated for the same time interval. Values of $r^{2}$ for $\mathrm{O}_{2}$ and $\mathrm{POC}$ linear regressions, respectively, are shown in parentheses

\begin{tabular}{|c|c|c|c|}
\hline $\begin{array}{l}\text { Location } \\
\text { Date }\end{array}$ & $\begin{array}{c}\mathrm{BGE}_{\text {time }} \\
(\%)\end{array}$ & $\begin{array}{c}\mathrm{BGE}_{\max } \\
(\%)\end{array}$ & $\begin{array}{c}\text { Ratio } \\
\left(\mathrm{BGE}_{\max } / \mathrm{BGE}_{\text {time }}\right)\end{array}$ \\
\hline \multicolumn{4}{|l|}{ Esrum } \\
\hline Mars & $36 \pm 10(0.95,0.97)$ & $65 \pm 12$ & 1.8 \\
\hline $\operatorname{Mar}^{\mathrm{d}}$ & $39 \pm 5(0.84,0.78)$ & $39 \pm 4$ & 1.0 \\
\hline Apr $r^{-1}$ & $43 \pm 7(0.93,0.90)$ & $75 \pm 3$ & 1.8 \\
\hline May' & $53 \pm 4(0.97,0.96)$ & $76 \pm 5$ & 1.4 \\
\hline May $^{b}$ & $14 \pm 8(0.94,0.60)$ & $38 \pm 7$ & 2.5 \\
\hline $\operatorname{Dec}^{b}$ & $22 \pm 2(0.98,0.99)$ & $38 \pm 5$ & 1.7 \\
\hline $\mathrm{Feb}^{\mathrm{b}}$ & $13 \pm 2(0.94,0.97)$ & $49 \pm 20$ & 3.3 \\
\hline Average & & & 1.8 \\
\hline \multicolumn{4}{|l|}{ Slotss $\varnothing$} \\
\hline $\operatorname{Jan}^{\mathrm{b}}$ & $16 \pm 4(0.93,0.97)$ & $40 \pm 7$ & 2.5 \\
\hline $\operatorname{Mar}^{a}$ & $59 \pm 10(0.91,1.00)$ & $67 \pm 10$ & 1.1 \\
\hline $\operatorname{Mar}^{d}$ & $45 \pm 10(0.99,0.71)$ & $58 \pm 3$ & 1.3 \\
\hline $\mathrm{May}^{\mathrm{b}}$ & $36 \pm 4(0.97,0.94)$ & $66 \pm 5$ & 2 \\
\hline May' & $53 \pm 8(0.82,0.99)$ & $63 \pm 6$ & 1.3 \\
\hline Average & & & 1.6 \\
\hline \multicolumn{4}{|l|}{ Stigsholm } \\
\hline Jul & $29 \pm 2(0.98,0.98)$ & $49 \pm 6$ & 1.8 \\
\hline $\begin{array}{l}\text { "Glass bo } \\
\text { 'Bag expe }\end{array}$ & $\begin{array}{l}\text { ttle experiments } \\
\text { eriments }\end{array}$ & & \\
\hline
\end{tabular}

\section{DISCUSSION}

Growth in dilution cultures is often characterized by a lag phase in cell replication followed by a log phase (Zweifel et al. 1993, Søndergaard \& Middelboe 1995, Carlson \& Ducklow 1996) where maximum growth efficiency is expected (Pirt 1982). When the concentration of organic substrate decreases below the saturation level, the growth rate decreases and the culture

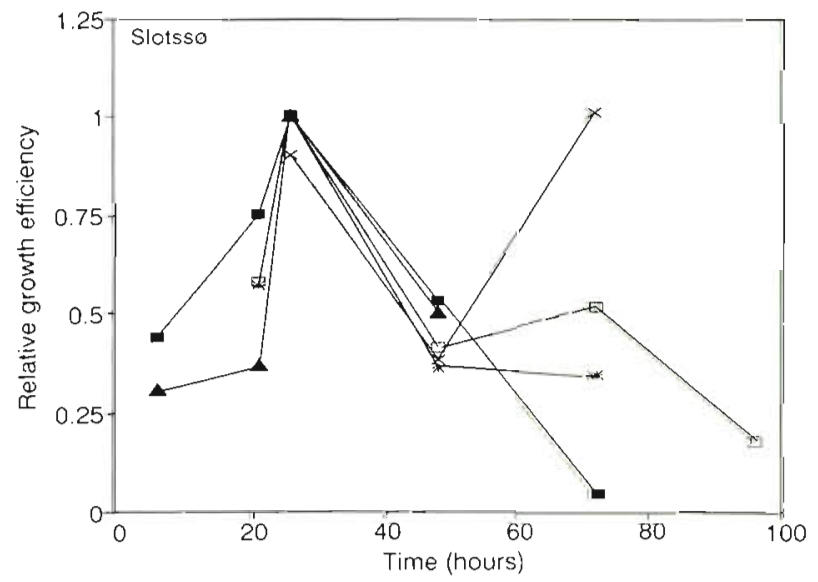

Fig. 5. Relative growth efficiency (unified with respect to $B G E_{\max }$ ) versus time in experiments from Frederiksborg Slotss $\varnothing$
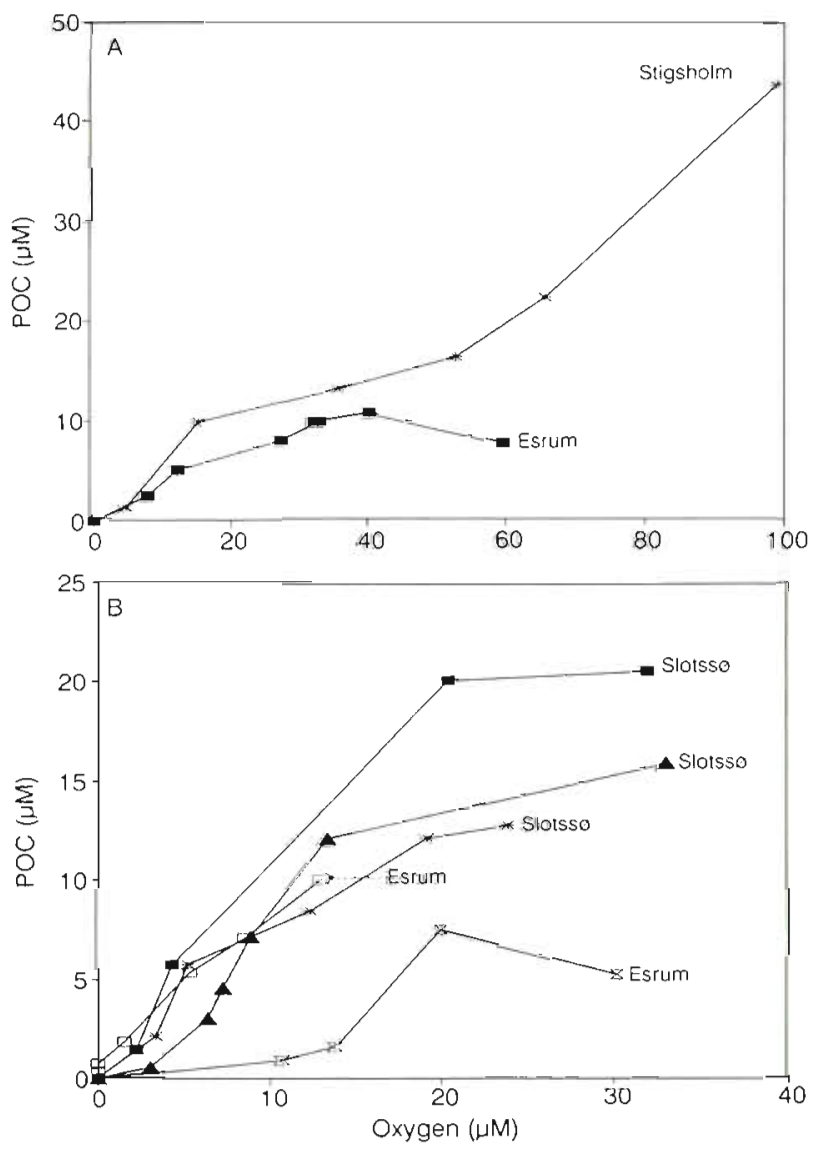

Fig. 4. $\mathrm{POC}$ versus $\mathrm{O}_{2}$ plots from experiments with water from (A) Stigsholm and Esrum and (B) Frederiksborg Slotss $\varnothing$ and Esrum. Notice the different scaling in (A) and (B)

enters the stationary phase where the relative importance of maintenance respiration increases until all energy is sequestered for maintenance purposes. At this point there is no net growth in the culture and the growth efficiency is by definition zero.

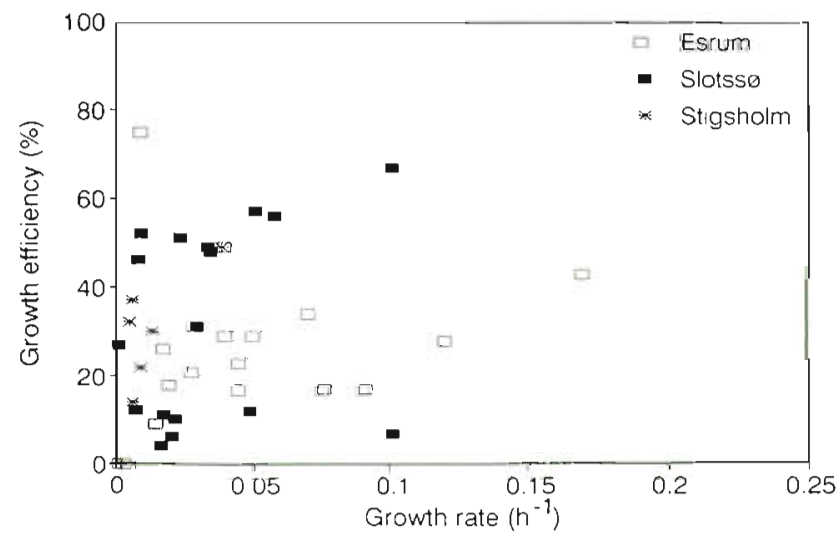

Fig. 6. Growth efficiency versus bacterial growth rate from the 9 growth experiments 
Several of our experiments behaved as predicted from the logistic model as mentioned above. The measured growth efficiencies were low during the lag phase, peaked during the log phase, most ofter decreased during the stationary phase, and eventually approached zero (Figs. 3B, 4 \& 5). The interpretation in the context of a logistic model is that the DOC pool initially is dominated by a single substrate or substrates of similar energetic value and that exhaustion of the pool results in progressively lower efficiencies, eventually to the point where BGE becomes zero. However, the decrease in BGE can also be explained by a shift among substrates over time. The primary substrates are those used first and with highest efficiency and gradually growth proceeds at the expense of substrates with less and less nutritional value (Connolly et al. 1992).

The reason for a lag phase and a concomitant low growth efficiency could be a metabolic shift after sample handling with energy spilling leading to short-term variability in growth efficiency (Russell \& Cook 1995). Whatever the reason(s) for the lag phase is, the inclusion of this phase in calculations of the efficiency will decrease the value. Likewise, the inclusion of any values from the stationary phase will decrease the calculated BGE compared with $\mathrm{BGE}_{\max }$. Although we only included data where the bacterial biomass (POC) increased in the efficiencies calculated from regressions, the result was that these time-integrated efficiencies on average were only about half the maximum values (Table 1). It is therefore important to define the period for calculation with respect to bacterial growth phases.

Some previous studies on growth efficiency have taken care not to include the stationary phase in the calculations (Tranvik 1988, Middelboe \& Søndergaard 1993). However, most published studies have included an eventual lag phase, which will decrease the efficiency values. The inclusion of the initial period is most often done with the argument that this is the period where the DOC of highest energetic value is utilized and thus should provide the highest efficiency (Connolly et al. 1992). This is not the case as demonstrated in the present study and such evidence can also be found in other studies. High values for oxygen and DOC utilization without an apparent cell growth and without increases in bacterial biomass (the lag phase) can be seen in the data presented by Coffin et al. (1993), Carlson \& Ducklow (1996) and Cherrier et al. (1996). Carlson \& Ducklow (1996) excluded the lag phase from their calculations of growth efficiency.

The time sequence in DOC utilization and growth efficiency cannot always be described in agreement with a logistic model. In the experiment from Lake Stigsholm (Fig. 2B) and 1 experiment from Frederiks- borg Slotssø (Fig. 5), BGE had 2 peaks and increased rather late during the incubation and at a time when the community growth rate was approaching zero. One explanation for this result could be a change in the community structure and development of a bacterial community with an efficient exploitation of polymers and more refractory compounds. A high growth rate of such specific bacteria might be masked by the high total number of bacteria. Another explanation could be a variation caused by shifts up and down in the energy metabolism and kinetic parameters during an eventual bacterial succession (Russell \& Cook 1995). The observed increases in BGE concomitant with a decrease in community growth rates help to explain why the expected positive relationship between BGE and growth rate (Pirt 1982, Middelboe et al. 1992) was not present.

Growth efficiency has to be measured in a predatorfree culture. Flagellates were not present, but viruses can be a potential mortality factor in the experiments, especially after prolonged incubation (Tuomi et al. 1995) and can cause cryptic growth based on recycled bacterial biomass (Novitsky 1986). However, the presence of viruses probably decreases the growth efficiency (Middelboe et al. 1996) and cannot offer any coherent explanation for a high $\mathrm{BGE}$ late during the incubations as POC then should decrease and the BGE values become negative. Aside from the experiment with water from Stigsholm all our incubations were of such short duration that any effects due to viruses and predatory bacteria were probably negligible.

Our conclusion is that if maximum values of $B G E$ with respect to the ambient pool of DOC are wanted, the biomass and respiration, and possibly DOC during regrowth, have to be measured with an appropriate time scale. A plot of $P O C$ versus $\mathrm{O}_{2}$ can be used to evaluate variations in $B G E$ and has the advantage that time is removed as a variable. Such a procedure can identify uncorrelated changes among bacterial respiration and other measures of bacterial activity in dilution cultures and undisturbed samples. Uncorrelated changes have previously been shown to occur within a few hours or at longer time scales (Coffin et al. 1993, Biddanda et al. 1994, Pomeroy et al. 1994). However, the consequences for BGE have hardly been discussed (Coffin et al. 1993) and most published experiments do not allow a quantitative evaluation of the BGE underestimation, which can occur.

An important matter of concern with respect to a comparison between experimentally derived and true in situ BGE is that any filtration procedure inevitably interrupts the expected close linkage between substrate production and utilization and that bacterial succession in the container most probably occurs. Likewise, regeneration of inorganic nutrients by zoo- 
plankton is interrupted. To what extent these potential problems affect BGE is not known. As DOC and not inorganic nutrients is limiting in the studied lakes, we do not expect to have induced changes by nutrient additions (Zweifel et al. 1993). The general assumptions for dilution cultures are that for a short period the substrate concentration and composition in the culture are identical to those in situ and accordingly should be utilized with an efficiency controlled by substrate properties and not by the types of bacteria.

We do not claim that $B G E_{\max }$ is the best prediction of in situ growth efficiency, but some of the low values in the literature - including some of our own - could find their explanation just in the procedures used for measurement and calculation. It should be emphasized that we have used a RQ of 1 , and the most likely deviation is $R Q<1$ (Søndergaard \& Borch 1992), which would elevate the BGE values presented. Ideally, growth efficiency should be measured directly in carbon units with a combination of decrease in DOC, POC for the biomass increases, and $\mathrm{CO}_{2}$ for respiration. Due to a high background of DOC from 0.5 to $1 \mathrm{mM}$ and inorganic carbon at about $2 \mathrm{mM}$ the ability to detect rather small changes did preclude their usage in the present study and the more sensitive oxygen and POC measurements were chosen. POC measurements of bacterial biomass with GF/F filters are not ideal, as small bacteria can escape capture, however, the alternative of counting, sizing, and the choice of a biovolume conversion factor does not seem more attractive. A comparison with the frequency distribution of growth efficiency measurements published by Cole \& Pace (1995) places most of our BGE max values (38 to $76 \%$ ) on the high side of the midpoint range (40 to $50 \%$ ) and most values calculated by regression within or below the midpoint range. Furthermore, the overall variability of $\mathrm{BGE}_{\max }$ was 2 -fold and thus much lower than the 4.5-fold $\mathrm{BGE}_{\text {time }}$ variation. Compared with recent low efficiency estimates from marine areas, which are all low productive areas compared with the studied lakes, our data support the suggestions of a generally higher efficiency in eutrophic conditions (Griffith et al. 1990, Biddanda et al. 1994, Pomeroy et al. 1995, Carlson \& Ducklow 1996).

It has been stated (Jahnke \& Craven 1995) that measurements of bacterial production and the use of uncertain growth efficiency estimates do not constrain the metabolic importance of bacteria and that whole community respiration should be used. No doubt, measurements of in situ respiration and specifically bacterial respiration are in short supply, but the study by Pomeroy et al. (1995) does emphasize the problems inherent in a conversion of production and respiration measurements to growth efficiency values. Until we develop an independent method to measure in situ growth efficiencies and understand more about the controlling factors, we probably have to accept uncertainties aside from the natural variability most probably reflected in published values (Cole \& Pace 1995). However, to avoid calculation of too low efficiency values and to learn more about the utilization of natural DOC, more attention must be directed to define bacterial growth phases and the development of growth efficiency in growth experiments.

Acknowledgements. Discussions with Peter Koefoed Bjornsen and comments by Richard Coffin and the reviewers are appreciated as are the technical skills of Gitte Jacobsen and Diana Fuhrman. This study was supported by the Danish Natural Science Research Council and the Danish Environmental Research Programme. This is publication no. 664 from the Freshwater Biological Laboratory.

\section{LITERATURE CITED}

Azam F, Fenchel T, Field JG, Gray JS, Meyer-Reil LA, Thingstad F (1983) The ecological role of water-column microbes in the sea. Mar Ecol Prog Ser 10:257-263

Baines SB, Pace ML (1991) The production of dissolved organic matter by phytoplankton and its importance to bacteria: patterns across marine and freshwater systems. Limnol Oceanogr 36:1078-1090

Benner R, Lay J, K'nees E, Hodson RE (1988) Carbon conversion efficiency for bacterial growth on lignocellulose: implications for detritus-based food webs. Limnol Oceanogr 33:1514-1526

Biddanda B, Opsahl S, Benner R (1994) Plankton respiration and carbon flux through bacterioplankton on the Louisiana shelf. Limnol Oceanogr 39:1259-1275

Bjornsen PK (1986) Bacterioplankton growth yield in continuous seawater cultures. Mar Ecol Prog Ser 30:191-196

Bjernsen PK, Kuparinen J (1991) Determination of bacterioplankton biomass, net production and growth efficiency in the Southern Ocean. Mar Ecol Prog Ser 71:185-194

Carlson CA, Ducklow HW (1996) Growth of bacterioplankton and consumption of dissolved organic carbon in the Sargasso Sea. Aquat Microb Ecol 10:69-85

Cherrier J, Bauer JE, Druffel ERM (1996) Utilization and turnover of labile dissolved organic matter by bacterial heterotrophs in eastern North Pacific surface waters. Mar Ecol Prog Ser 139:267-279

Coffin RB, Connolly JP, Harris PS (1993) Availability of dissolved organic carbon to bacterioplankton examined by oxygen utilization. Mar Ecol Prog Ser 101:9-22

Cole JJ, Pace ML (1995) Why measure bacterial production? A reply to the comment by Jahnke and Craven. Limnol Oceanogr 40:441-444

Connolly JP, Coffin RB, Landeck RE (1992) Modelling carbon utilization by bacteria in natural water systems. In: Hurst CJ (ed) Modelling the metabolic and physiologic activities of microorganisms. J Wiley \& Sons Inc, New York, p $249-276$

Goldman JC, Caron DA, Dennett MR (1987) Regulation of gross growth efficiency and ammonium regeneration in bacteria by substrate C:N ratio. Limnol Oceanogr 32 : $1239-1252$

Griffith PC, Douglas DJ, Wainright SC (1990) Metabolic activity of size fractioned microbial plankton in estuaries, nearshore and continental shelf waters of Georgia. Mar Ecol Prog Ser 59:263-270 
Hansen LS, Holmer M, Blackburn TH (1993) Mineralization of organic nitrogen and carbon (fish food) added to anoxic sediment microcosms: role of sulphate reduction. Mar Ecol Prog Ser 102:199-204

Ho KP, Payne WJ (1979) Assimilation efficiency and energy contents of phototrophic bacteria. Biotechnol Bioeng 21 $787-802$

Jahnke RA, Craven DB (1995) Quantifying the role of heterotrophic bacteria in the carbon cycle: a need for respiration measurements. Limnol Oceanogr 40:436-441

Kirchman DL, Suzuki Y, Garside C, Ducklow HW (1991) High turnover rates of dissolved organic carbon during a phytoplankton bloom. Nature 352:612-614

Kroer N (1993) Bacterial growth efficiency on natural dissolved organic matter. Limnol Oceanogr 38:1282-1290

Linley EAS, Newell RC (1984) Estimates of bacterial growth yields based on plant detritus. Bull Mar Sci 35:409-425

Middelboe M, Jorgensen NOG, Kroer N (1996) Effects of virus on nutrient turnover and growth efficiency of noninfected marine bacterioplankton. Appl Environ Microbiol 62:1991-1997

Middelboe M, Nielsen B, Sondergaard M (1992) Bacterial utilization of dissolved organic carbon (DOC) in coastal waters - determination of growth yield. Arch Hydrobiol Ergebn Limnol 37:51-61

Middelboe M, Sondergaard M (1993) Bacterioplankton growth yield: seasonal variations and coupling to substrate lability and $\beta$-glucosidase activity. Appl Environ Microbiol 59:3916-3921

Novitsky JA (1986) Degradation of dead microbial biomass in a marine sediment. Appl Environ Microbiol 52:504-509

Pirt SJ (1982) Maintenance energy: a general model for energy-limited and energy-sufficient growth. Arch Microbiol 133:300-302

Pomeroy LR, Sheldon JE, Sheldon WM Jr (1994) Changes in bacterial numbers and leucine assimilation during estima-

Responsible Subject Editor: J. Dolan, Villefranche-sur-Mer, France tions of microbial respiratory rates in seawater by the precision Winkler method. Appl Environ Microbiol 60: $328-332$

Pomeroy LR, Sheldon JE, Sheldon WM Jr, Peters F (1995) Limits to growth and respiration of bacterioplankton in the Gulf of Mexico. Mar Ecol Prog Ser 117:259-268

Porter KG, Feig YS (1980) The use of DAPI for identifying and counting aquatic microflora. Limnol Oceanogr 25:943-948

Riemann B, Sondergaard M (eds) (1986) Carbon dynamics in temperate, eutrophic lakes. Elsevier, Amsterdam

Russell JB, Cook GM (1995) Energetics of bacterial growth: balance of anabolic and catabolic reactions. Microbiol Rev 59:48-62

Schwærter S, Sondergaard M, Riemann B, Jensen LM (1988) Respiration in eutrophic lakes: the contribution of bacterioplankton and bacterial growth yield. J Plankton Res 10: $515-531$

Søndergaard M, Borch NH (1992) Decomposition of dissolved organic carbon (DOC) in lakes. Arch Hydrobiol Beih Ergeb Limnol 37:9-20

Sondergaard M. Middelboe M (1993) Measurements of particulate organic carbon: a note on the use of glass fiber (GF/F) and Anodisc filters. Arch Hydrobiol 127:73-85

Sondergaard M, Middelboe M (1995) A cross-system analysis of labile dissolved organic carbon. Mar Ecol Prog Ser 118: $283-294$

Tranvik L (1988) Availability of dissolved organic carbon for planktonic bacteria in oligotrophic lakes of differing humic content. Microb Ecol 16:311-322

Tuomi P, Fagerbakke KM, Bratbak G. Heldal M (1995) Nutritional enrichment of a microbial community: the effects on activity, elemental composition, community structure and virus production. FEMS Microb Ecol 16:123-134

Zweifel UL, Norrman B, Hagström $\AA$ (1993) Consumption of dissolved organic carbon by marine bacteria and demand for inorganic nutrients. Mar Ecol Prog Ser 101:23-32

Manuscript first received: February 2, 1996

Revised version accepted: January 6, 1997 